\title{
Determinants of judges' career choices and productivity: a Polish case study
}

\author{
Przemysław Banasik ${ }^{1}$ Katarzyna Metelska-Szaniawska ${ }^{2}$. \\ Małgorzata Godlewska ${ }^{3}$. Sylwia Morawska ${ }^{3}$
}

Accepted: 6 January 2021 / Published online: 29 January 2021

(c) The Author(s) 2021

\begin{abstract}
The goal of this paper is to identify factors which affect judges' productivity and career choice motives with the view of increasing judicial efficiency. Specifically, the investigation focuses on such aspects as judges' remuneration, promotion, threat of judgment revocation, service/mission, periodic assessment, the threat of a complaint about protracted proceedings or of disciplinary proceedings, the threat of destabilization of the employment relationship, status/prestige of the profession, power/authority, social recognition, leisure, as well as administrative supervision and self-monitoring. To this end, a survey was conducted among judges of three of the largest Polish regional courts and subordinate district courts. The descriptive and statistical analyses show that judges' care for the number of cases resolved, proxying for their productivity, is significantly correlated with self-monitoring of their adjudication activity. The stability of employment, the status/prestige of the profession and a relatively high remuneration are the most important factors in terms of judges' career choices. In their care for the number of cases resolved remuneration is, albeit, no longer a relevant factor. Judges monitor their productivity due to reasons other than remuneration, possibly the sense of service/mission and the threat of various adverse consequences, the evidence for which is, however, also rather weak.
\end{abstract}

Keywords Judges' productivity · Judges' motivation · Judicial efficiency · Postsocialist countries

JEL Classification K40

Sylwia Morawska

smoraw@sgh.waw.pl

Extended author information available on the last page of the article 


\section{Introduction}

A well-functioning judiciary constitutes one of the crucial components of the institutional framework which affects countries' successful economic performance. Viewed from this perspective, the role of the judiciary primarily consists in securing two key prerequisites of the market economy: the protection of property rights and the enforcement of contracts-contributing, via both channels, to the efficient production and distribution of goods and services (OECD 2013). An inefficiently functioning judiciary may also lead to other consequences, including a loss in legitimacy of the political system or citizens' trust in the legal system, as well as pose a threat to the protection of individual freedoms (Ramello and Voigt 2012; Voigt 2016; Magalhães and Garoupa 2020). Judicial efficiency depends in turn on a number of factors that have been intensively studied, including empirically, over the last two decades (see Voigt 2016 for a survey of much of this literature). While these studies have brought several consistent conclusions, interestingly, they have failed to arrive at a consensus concerning whether the number of judges as such matters in this respect. One possible reason for such inconsistent findings is certainly the fact that judges differ in terms of their individual productivity levels. This merits an investigation of a deeper question, namely what drives the behavior of judges, in particular the care and effort that they put into adjudication activity.

The problem of judicial motivation and incentives is not a new topic in crossdisciplinary research bridging law, economics, sociology, psychology, and political science. In this paper, we draw on this literature with the aim of identifying the factors which affect judges' productivity and their underlying career choice motives for the case of Poland. Despite a fairly successful political and economic transition, this country, as with many other post-socialist states, is constantly struggling with significant court delays and other judicial efficiency problems (see comparative analyses in CEPEJ 2018 or European Commission 2018). At the same time, Poland is placed second in the European Union as far as the total number of judges is concerned (9980 professional judges in $2016^{1}$ ), and is also among those few states for which it has been confirmed - in a very recent study (Bełdowski et al. 2020) — that the number of judges does indeed matter when it comes to the efficiency of the judiciary. The deeper question concerning factors affecting individuals' decisions to pursue a career in the Polish judiciary and their subsequent productivity levels as judges has, however, not been tackled in the existing literature. Our study, therefore, aims to fill this lacuna.

Most existing works interested in the empirical verification of judicial incentives offer statistical or econometric analyses based on data including, inter alia, court output, judges staffing, and some individual judges' characteristics (e.g. age or education), obtained from the relevant courts or national ministries of justice. We take a different approach and conduct an original survey among judges of Poland's three of

\footnotetext{
1 CEPEJ (2018). According to data obtained from the Ministry of Justice of Poland for 2019, 9720 judges adjudicate in Polish common courts (Eukaszewicz 2019). The number of judges has, therefore, not significantly changed in the last few years.
} 
the largest regional courts, located in different parts of the country, and subordinate district courts (with 252 judges responding to the questionnaire, that is, $2.53 \%$ of all judges currently adjudicating in Poland). The possibility of obtaining direct information from judges by means of a questionnaire allows us to significantly enrich the examination of their motivations and enables us to develop a better understanding thereof. Specifically, the information that the respondents revealed was used to explore the factors which affect judges' productivity and career choice motives, relating to, e.g., remuneration, promotion, threat of judgment revocation, service/ mission, periodic assessment, the threat of a complaint about protracted proceedings, the threat of disciplinary proceedings, the threat of destabilization of the employment relationship, status/prestige of the profession, power/authority, social recognition, leisure, as well as administrative supervision and self-monitoring. We also investigate whether a significant statistical dependence between the attitude of judges in terms of care for resolving cases and any of these factors exists.

The main results of our study reveal that the degree of self-monitoring among judges is significantly correlated with their care for the number of cases resolved. The stability of the employment relationship, the status/prestige of the profession, and remuneration are the most important factors in terms of judges' career choices. In their care for the number of cases resolved, i.e. productivity, remuneration is, albeit, no longer a relevant factor. Judges monitor their productivity due to reasons other than remuneration, possibly the sense of service/mission and the threat of various adverse consequences, the evidence for which is, however, also rather weak.

In recent years Poland has witnessed the implementation of several judicial reforms and a number of others are at the draft stage, possibly also pertaining to the remuneration system for judges. While bearing in mind that judges' behavior may be characterized by inertia in work habits, which may mitigate or slow down the effects of pro-efficiency changes in the regulatory framework within which courts and judges operate (Eisenberg and Huang 2012), the conclusions of our study may, nevertheless, provide decision makers in this area with a scientifically grounded basis for valuable recommendations.

To the best of our knowledge, this is one of the very first attempts to study factors affecting judicial motivation focused specifically on judges in a post-socialist country and based on data extracted directly from judges using surveys and interviews. ${ }^{2}$ These countries occupy the top spots in the per capita rankings of the number of judges in Europe, ${ }^{3}$ presumably as a result of a certain socialist legacy consisting in the relatively extensive jurisdiction of courts on the one hand, and the lack of simplified procedures on the other (Siemaszko et al. 2016). Our results, therefore, can also be regarded as providing insights concerning the validity of the main predictions of the economic approach to explaining judicial motivations for such a specific setting.

\footnotetext{
${ }^{2}$ Dimitrova-Grajzl et al. (2012b) provide an important earlier empirical study of the determinants of judicial productivity in another post-socialist country-Slovenia-however based on data concerning individual judges' characteristics extracted from lower courts statistics.

3 Seven of the first 10 member states of the European Union ranked according to the number of judges per 100,000 inhabitants are post-socialist countries, with Poland occupying ninth place (CEPEJ 2018).
} 
They also bring value added by verifying our knowledge of factors inducing judges' productivity in a country where the number of judges matters to the efficiency of the judiciary as a whole.

The paper is structured as follows. In Sect. 1 we survey the available literature concerning judicial motivation and, in particular, factors affecting the productivity of judges. Rooted mainly in public choice and law and economics, these studies constitute an important background for our empirical study. Section 2 provides a brief overview of some aspects of the organization and functioning of the Polish judiciary that are relevant from the point of view of this study. In Sect. 3 we describe the methodology of our empirical approach aimed at investigating factors affecting individuals' decisions to pursue a career in the Polish judiciary and their subsequent productivity as judges, while Sect. 4 presents and discusses the results obtained. The paper finishes with conclusions.

\section{Literature survey and theoretical background}

This project is a response to the research trend which is interested in exploring incentive schemes for judges which affect their productivity and, more broadly, literature analyzing factors affecting the efficiency of the judicial system as a whole. Empirical research, rooted in economics, investigates the latter factors from the perspective of supply and demand. According to a recent survey of this literature (Voigt 2016, see p. 189), potential factors on the supply side (i.e. affecting courts' output) include: the number of judges (as well as some of their characteristics, including education and experience); the incentives that judges are subject to (in particular, payment schemes and career possibilities); the number and quality of available court staff; accessible technology; the complexity of the judicial system ${ }^{4}$; the budget of the judiciary; the number of non-judicial tasks allocated to the judiciary; the percentage of vacancies ${ }^{5}$; and the complexity of the cases filed.

With regard to the role of the number of judges in terms of judicial efficiency, both theoretical argumentation and empirical evidence remain inconclusive. On the one hand, a positive relationship can be expected, as more judges should allow, ceteris paribus, for the resolution of more cases. On the other hand, however, as demonstrated by Beenstock and Haitovsky (2004) for the case of Israeli courts, increasing the number of judges can lead incumbent judges to decrease their productivity levels (taking advantage of the situation and reducing their workload where possible), in effect offsetting the impact that the employment of new judges has on the overall number of resolved cases. ${ }^{6}$ An important channel via which this effect materializes is connected with the supervision of judges by court presidents (or other

\footnotetext{
4 As well as the degree of formality of judicial procedures (see e.g. Djankov et al. 2003; Di Vita 2010).

5 A related issue of voluntary and mandatory judge turnover between judicial districts has also been addressed by Guerra and Tagliapietra (2017).

6 This problem has earlier been signaled by Tjoflat (1993) in a short opinion paper arguing that "more judges" mean "less justice" (p. 70).
} 
superiors). As Beenstock and Haitovsky (2004) argue, judges under supervision are more productive, so since more judges will often signify overall less stringent supervision, a tendency to decrease productivity will develop among judges when their number increases. Some of the most comprehensive empirical studies of the topic to date-Dimitrova-Grajzl et al. (2012a, 2014) for Slovenian courts and Voigt and El-Bialy (2015) for member states of the Council of Europe-did not find a significant relationship between the number of judges and judicial efficiency; while Christensen and Szmer (2012) for the US Courts of Appeals and, recently, Bełdowski et al. (2020) for the case of Polish commercial courts, did identify such a meaningful effect.

Several individual characteristics of judges have also been found to affect judicial productivity, and thereby the efficiency of the judiciary. In particular, this concerns judges' educational background, a proxy for their intellectual abilities (e.g. Landes et al. 1998; Choi et al. 2012; Ramseyer 2012), as well as their expertise, which in principle increases in step with age, but which may be offset by a possible burnout effect in cases of longer tenure (Christensen and Szmer 2012).

For this paper, the second element of Voigt's (2016) list of potential factorsjudges' incentives - is of crucial interest. Nearly 50 years ago, Posner (1973, p. 415) suggested that "judges, like other people, seek to maximize a utility function that includes monetary and non-monetary elements (the latter including leisure, prestige, and power)". This statement marked the beginning of an economic analysis of judges' motivation. Located at the intersection of economic analysis of law and public choice, presupposing that all political actors are driven by their own interests and act rationally, this emerging literature relied heavily on the assumptions of methodological individualism and rational choice. ${ }^{7} \mathrm{With}$ regard to judicial behavior, Posner (1973) also put forward a hypothesis that, in resolving cases, judges aim to impose their own system of preferences and values on society and derive positive utility from such actions. Kimenyi et al. (1985) built on that theory and tested it empirically. As the basis for their study, they assumed that judges draw utility from the remuneration that they receive in connection with their professional function and from the number of cases in which they issue rulings (thus imposing their preferences on society). Since judges do not determine their own salary, the only way for them to increase utility is through increasing the number of cases that they resolve. Their empirical findings, based on data for US state judges, indicate however a typically "economic" motivation of judges, i.e. striving to maximize monetary income. In cases when judges have no say in their remuneration, they adjust the number of cases resolved to align the marginal product with the pre-determined level of their salary.

\footnotetext{
7 Obviously, rational choice theory has been criticized on various grounds, including in relation to its application to problems falling within the scopes of interest of public choice and law and economics. Nevertheless, it remains the leading concept in the explanation of human behavior by economists. Naturally, approaches incorporating a psychological (e.g. Foxall 2004; Baum 2010), evolutionary (e.g. Marciano and Khalil 2012), and sociological (Gomes et al. 2016) perspective in scholarship on judicial behavior and efficiency have also been developing, but they mainly fall beyond the scope of this study.
} 
Other early approaches to the study of judicial motivation from an economic perspective include Landes and Posner (1980), Higgins and Rubin (1980), Cooter (1983), and Cohen $(1991,1992) .{ }^{8}$ Utility-based considerations of judicial behavior were further developed by Posner's (1993) article published under the meaningful title: "What Do Judges and Justices Maximize? (The Same Thing Everybody Else Does)". Based on a study for appellate judges in the US, Posner (1993)argued that judges are rational and "pursue instrumental and consumption goals of the same general kind and in the same general way that private persons do" (Posner 1993, p. 39). He also proposed an extended version of the utility function of a judge that incorporates, in its basic form, the time devoted to adjudication, the time devoted to leisure, pecuniary income, judicial salary, reputation, and other aspects including popularity, prestige, and avoiding the reversal of judgments issued. This study supplied further stimuli for other researchers to undertake this topic (e.g. Macey 1994; Miceli and Cosgel 1994; Baum 1997, 2006; Schauer 2000; Taha 2004; Choi et al. 2009; Shepherd 2011), providing for the confirmation of numerous goals, motives, and preferences that can explain judicial behavior, including pecuniary aspects, such as salary and income.

Building on several of these findings, another approach to judicial motivation was offered by Posner (2008) and further developed by Epstein et al. (2013), blending the economic time-allocation model with political scientists' emphasis on ideology and legal scholars' interest in legal motivations. According to this view, given their time constraints, judges seek to maximize their preferences over the following set of personal factors (which also have implications for ideological and legal goals): job satisfaction, external satisfactions, leisure, salary/income, and promotion. Epstein and Knight (2013) surveyed much of the empirical literature providing evidence for subsequent elements in judges' personal utility functions perceived in this way.

In a more recent study for the member states of the Council of Europe, Voigt and El-Bialy (2015) found no robust correlation between material incentives, such as bonus payments, other benefits (housing, cars, etc.) or sanctions and judges' higher resolution rates. However, they did identify such a positive correlation for judges' training opportunities. This is connected with the broader issue of the role of career prospects in the behavior of judges. If these prospects are dependent on merit, one should expect judges to invest in those aspects of their career that are rewarded. Voigt (2016) argued that this can, for instance, take the form of signaling competence by producing decisions that are not reversed by higher courts, ${ }^{9}$ or signaling effort by producing a high number of (or simply lengthy) decisions. ${ }^{10}$ Melcarne and Ramello (2015) argued that the degree of judicial independence from political interference, which can also be viewed as the degree to which judges may feel that their chances of future promotion do not depend on politicians' volatile will but rather

\footnotetext{
${ }^{8}$ For a brief survey, see Kornhauser (2000).

9 An important study of how the possible threat of judgment revocation affects judges' incentives and productivity has been conducted by Choi et al. (2012).

${ }^{10}$ Hansford et al. (2010), however, indicate that the role of career prospects is dependent on the actual point in the judge's career (which, obviously, is dependent on the judge's age to a significant extent).
} 
on their personal capacities and work effort, might be a factor affecting the career incentives of judges, and thereby their performance. In their empirical study for member states of the Council of Europe, these authors found confirmation of such a mechanism and argued that it may not only incentivize judges to work harder but also affect the aggregate enhanced performance of the entire justice sector.

Determinants of judicial productivity (understood as the ability of judges to resolve cases) at post-socialist courts have been studied by Dimitrova-Grajzl et al. (2012b) for the case of Slovenian first-instance courts. With regard to judge's demographic characteristics, based on judge-level data from these courts, the authors find that judicial productivity initially increases with age and subsequently decreases as judges approach retirement (i.e. there exists an inverse U-shaped age-productivity relationship consistent with the life-cycle hypothesis). Judges' education (possessing a graduate degree), experience on the bench, and gender do not matter in this respect. Two other aspects are, however, found to play a role-judges' salaries, which are found to be significantly positively associated with judicial productivity, and incentives provided by judges' career prospects (specifically, judges who are up for promotion tend to resolve more cases in the year preceding their promotion decision year than judges who are not). Finally, when talking about judicial productivity and incentives, one should bear in mind that, from a social point of view, the ultimate goal need not be the maximum number of judicial decisions issued by a judge; the quality of these decisions also plays a significant role, and incentives should be structured in such a way that quality of adjudication is sufficiently rewarded (Voigt 2016). Ash and McLeod (2015) estimate the effects of changes in judges' employment conditions on judicial performance, based on data from US state supreme courts, with particular focus on intrinsic motivation. Their approach combines the time-allocation model of judicial behavior proposed by Epstein et al. (2013) and the broad literature on public sector incentives. Specifically, they assume that judges also prefer to work on important cases that can influence the law in the future. They indeed find that judges are intrinsically motivated to provide high-quality decisions, preferring, at the margin, quality over quantity. Higher quality judgments (which are cited more often by other judges) are produced under less time pressure and when judges have more discretion in selecting the cases that they handle. Dimitrova-Grajzl et al. (2012b) also study whether increasing judicial productivity would come at the expense of reducing quality of judicial decision-making in the case of one of the post-socialist countries-Slovenia. Using data on appealed and overturned cases as proxies for the quality of judicial decision-making, they identify such a quantityquality trade-off (i.e. that more productive judges make lower-quality decisions) at local courts (and possibly also labor and social courts), but not at district courts. In a study for another post-socialist country, Dimitrova-Grajzl et al. (2015) draw on court-level data from Bulgaria and find that increasing court productivity does indeed decrease adjudicatory quality.

Our study of the factors affecting a person's decision to pursue a career in the judiciary and their subsequent productivity as a judge, conducted for the case of Poland, attempts in particular to answer the basic question of whether judges' productivity is determined merely by material motives or also related to the other stimuli mentioned in this section, as well as which aspects determine judges' career 
choices. While investigating whether certain factors can induce judges to work harder, we also account for the quality of adjudication dimension. Before embarking on the empirical study, in the next section we briefly present the relevant basic information concerning the Polish judiciary.

\section{Basic information about the Polish judicial system and judges}

Pursuant to Article 175(1) of the Constitution of the Republic of Poland of 2 April $1997,{ }^{11}$ the justice system in Poland is governed by the Supreme Court, common courts, administrative courts, and military courts. There are 374 common courts in Poland, including 11 courts of appeal, 45 regional courts, and 318 district courts (Ministry of Justice 2016a). The task of the district courts is to issue rulings in the first place in civil, family, labour law and social, economic and criminal insurance cases. The regional courts review appeals against decisions made by the district courts. The regional courts also deal with the recognition of difficult civil, family, labour and social, economic and criminal insurance law in the first instance. The task of the courts of appeal is to hear appeals against decisions made by the regional courts. Detailed information about the judiciary in Poland can be found in "Appendix 1".

A total of 6738 judges adjudicate at district courts, 2552 at regional courts, and 440 at courts of appeal (Eukaszewicz 2019, citing Ministry of Justice data for 2018). Working at the court of appeal is a great honour for a judge and is associated with prestige in the judicial environment. Judges with relatively longer experience and outstanding legal knowledge should work in the courts of appeal due to the difficulty of the cases that they handle. However, practice shows that this is not always the case. Any judge from a district or regional court may be delegated to the court of appeal. There are no rules in this respect. Apart from prestige, working at a court of appeal is not associated with any additional gratuities. The courts lack assistants and well-run secretariats.

The remuneration of a judge in Poland depends on duration of service and the associated promotion rate, and to a limited extent on the court in which the judge serves. ${ }^{12}$ The lowest salary is at a district court, and the highest is at a court of appeal, which, however, is most often linked to lengthy work experience. The minimum basic remuneration for 2019 was PLN 9920 (gross) at a district court, and the maximum was PLN 15,630 (gross) at a court of appeal. ${ }^{13}$

\footnotetext{
11 Journal of Laws No. 78, item 483, with amendments.

12 The Act of 20 March 2009 changed the method of calculating remuneration for Polish judges. In accordance with the amended Art. 91 of the Act on the System of Common Courts, the remuneration of judges who occupy equivalent judicial posts, differs depending on the duration of service or functions performed. It should be noted that an increase in remuneration is independent of the judge's productivity, being instead correlated with development of the domestic economy as a whole (Citko 2015, p. 13).

13 Art. 91 and 91a of the Act on the System of Common Courts, Journal of Laws 2016, item 483, with amendments.
} 
For the year 2018, official statistics reported 15,049,054 cases incoming to common courts in Poland and 14,914,999 cases resolved by these courts (Ministry of Justice 2018). Appeals courts heard $1.4 \%$ of all types of cases, which were examined by $4.5 \%$ of the total number of common court judges. Regional courts received $14.3 \%$ of all types of cases, which were reviewed by $26.2 \%$ of the total number of common court judges. Last but certainly not least, district courts handled $84.3 \%$ of all types of cases, distributed among $69.2 \%$ of all common court judges. In Fig. 1a we present the number of cases incoming to common courts in Poland in the period 2011-2018 and the number of cases that these courts resolved, while Fig. 1b demonstrates the total number of common court judges in this period.

While both the number of incoming, as well as the number of resolved cases exhibit a slightly increasing trend (with some volatility), the number of judges remains relatively stable, or even decreases, according to data for 2018. This signifies that an increasingly large number of cases submitted to courts each year is distributed among the same (or even decreasing) number of judicial staff. Clearly, the question might arise as to what the limits of a judge's productivity are and whether this performance can potentially be increased. To this end, an economic model of judges' behavior should be analyzed, taking into consideration various factors discussed in Sect. 1.

\section{Research methods}

The empirical study of judges' career motives and productivity factors was carried out in this paper based on an original survey and a set of interviews conducted among judges of Polish regional and district courts. We aimed, in particular, to answer the question of whether Polish judges rationalize their behavior as far as productivity in handling cases is concerned, as well as what their motives for pursuing a career as a judge are.

The questionnaire that was constructed exclusively for this study consisted of 20 questions and was divided into two parts. In the first part, basic questions were asked concerning the judge's gender, work experience (duration in years), having children, and the type of court where the judge adjudicated. The second part contained questions aimed at collecting information which would allow to conduct the essential analysis of the paper. These questions related to the number of resolved cases, self-monitoring of a judge's productivity and the potential factors affecting it, as well as the motives underlying their choice to pursue a career as a judge. These questions differed in terms of methodology: some were closed (yes/no) questions; others required reporting answers as values on a given scale; and two were open-ended questions (asking for factors other than those mentioned in the survey that may influence a given judge's productivity or career choice). In questions that required the provision of certain values, the following scale was used: 0- "not at all", 1-"hardly", 2-“slightly (to some extent)", 3-“I try to take this into consideration", 4-"It is important to me", 5-“yes", 6-“definitely yes".

It was assumed that both the scope of the questions, as well as the overall number thereof, could not be extensive, so as not to discourage participants from completing 
(a) number of cases

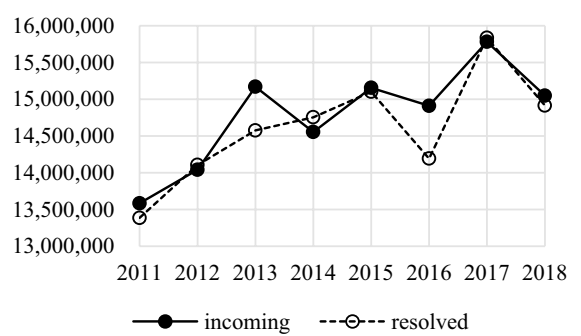

(b) number of judges

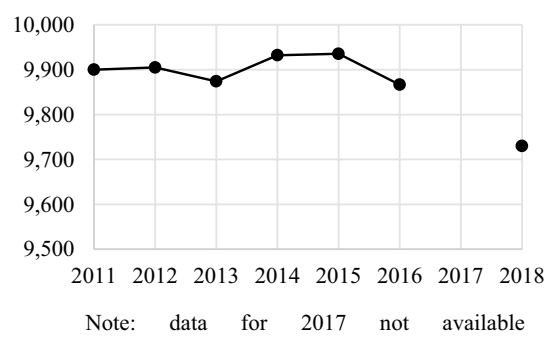

Fig. 1 Cases and judges at Polish common courts, 2011-2018. Source: Ministry of Justice (2016b, 2018), Łukaszewicz (2019) citing Ministry of Justice data

the questionnaire. ${ }^{14}$ In principle, no difficult or uncomfortable questions were formulated throughout the survey. Nevertheless, several questions proved troublesome for the respondents and the answers to these questions were left blank in a significant number of questionnaires. We report this problem, where relevant, in the description of the results that follows.

The survey was conducted between February and May 2015 among judges of Poland's three of the largest regional courts, located in different parts of the country, and subordinate district courts. ${ }^{15}$ The subject of the study was a single respondenta district or regional court judge ${ }^{16}$ — who personally and voluntarily filled out the questionnaire (without the participation of the researcher). The choice of regions and districts is of no particular relevance for the interpretability of our results, as courts in Poland operate in a uniform manner and are subject to the same regulations and principles. In addition, all judges are trained according to the same educational model, regardless of where they adjudicate and reside. The applicable conditions of the functioning of ordinary courts and judges in Poland, which have been described in more detail in Sect. 2 of the paper and in "Appendix 1", justify the following baseline assumptions for the study:

- each judge has a similar educational background and similar access to the process of continuing education;

\footnotetext{
14 From the point of view of survey analysis, judges are considered by the literature as "difficult populations" for a variety of reasons (connected e.g. with their perception of a particularly high status, a certain professional "remoteness" of the judiciary within society, significant time constraints, unwillingness to be tested, concerns about the confidentiality of responses, and even distrust or dislike of social and behavioral science and scientists - see Dobbin et al. 2001).

15 The names of these regions and districts have been deliberately anonymized so as to ensure the transparency of our research.

16 Because of the specificity of their position, our study does not include appeals court judges. Firstly, these judges adjudicate in top-tier courts within the ordinary court system, and thus the factors related to promotion and a possible resulting increase in remuneration will have, at best, a moderate impact on their productivity. Secondly, their performance is directly linked to the number of appeals that are submitted, not just the activity of a judge per se.
} 
- each judge has similar access to the literature and case law and each is IT-literate;

- cases are filed and monitored on the same basis in each court;

- the cases which judges resolve are marked by a similar degree of complexity, regardless of the place of adjudication;

- each court has the same organizational structure;

- there are no discrepancies in administrative supervision between the courts;

- the salary that judges receive depends solely on their work experience (in years), the type of court in which they adjudicate, and their position-the scheme for calculating this remuneration is regulated by the law, as mentioned in Sect. 2 and described in detail in "Appendix 1";

- the court's location does not influence judges' opinions concerning the drivers of their productivity as, inter alia, the location of the court where a judge adjudicates is independent of the judge's place of residence (i.e. judges may well adjudicate in courts located several kilometers away from where they live).

To sum up, the structure of the key characteristics referred to above, which are relevant to the entire population of judges, was retained in the sample used in our study. Surveys were made available to all judges in the relevant districts, with all questionnaires having been returned; however, as mentioned earlier, the answers to some questions were omitted. Overall, our study is based on 252 questionnaires, 79 of which come from regional court judges and 172 from district court judges. ${ }^{17}$ This signifies $2.53 \%$ of the active population of judicial staff in Poland at the moment of conducting the survey.

Given the reluctance of some judges to answer a number of questions from the survey, as mentioned earlier, efforts were made to fill this gap by conducting indepth interviews with some of the participants. During these interviews, questions were aimed, in particular, at finding out the actual causes of a particular course of action undertaken by individual judges. In addition, the veracity of the responses to some questions from the survey could be verified in this way. Altogether, 10 indepth interviews were conducted, with all interviewees having preferred to remain anonymous. The interviews took place in the same period as the survey upon judges giving their consent to be interviewed (in 15 cases, the interview request was rejected ${ }^{18}$ ), in favorable conditions, and allowing for freedom of expression.

All in all, given the difficult subject matter at hand, the questionnaires were a more valuable source of information for our study and had greater cognitive value than the interviews. In responding to the questions contained in the survey, respondents had a greater sense of anonymity and therefore answered them more freely. ${ }^{19}$

\footnotetext{
17 One respondent did not report the type of court.

18 This was due not only to the limited willingness of some participants to dedicate their time, but also to the reluctance to provide in-depth, detailed answers to questions in the examined subject area.

19 During the interviews, the respondents were obviously not anonymous to the researcher, and in some cases they gave the impression of being cautious in providing their responses due to a fear of the unauthorized disclosure of data.
} 
The interviews, however, made it possible to systematize the responses provided in the survey, extend the scope of questions, and enable their more specific formulation. The majority of the interview questions were explored only briefly in the questionnaire, and their reformulation and refinement during the meeting was encouraged by personal contact and an atmosphere favoring dialogue. Research in the form of an interview did not follow any pre-scheduled agenda, i.e. a concrete discussion guide, but instead proceeded by prompting the respondent to elaborate on matters of interest to the interviewer. The conversation was to better explain, and in part confirm, the responses provided in the questionnaire. The questionnaire, however, was simple to use, took less time and did not require as much engagement as the interview. We do not report the responses of the interviewees explicitly in subsequent parts of the paper, but we use the insights obtained as a background for the analysis of the data obtained from the survey and the conclusions which we formulate.

\section{Results and discussion}

\subsection{Descriptive data analysis}

The majority of respondents of our survey were women $(69 \%){ }^{20}$ Such a result is not surprising, as according to the National Council of Judiciary statistics (available for the year 2012), $65 \%$ of all district court judges and $61 \%$ of all regional court judges in Poland are female (National Council of the Judiciary 2012). With regard to duration of work experience, the largest group of respondents were judges with $10-15$ years and over 20 years of such experience (29\%, in each case), while the smallest group comprised those who had less than five years of experience (12\%). These percentages are also in line with the aforementioned data from the National Council of Judiciary (2012). The vast majority of the respondents had children $(83 \%)$, and more than two-thirds of them adjudicated in district courts (69\%).

The study of factors motivating judges' productivity focuses on the effort that they put into adjudication. With this in mind, the crucial question that we asked the respondents in our questionnaire concerned whether they care about the number of cases resolved in a given settlement period (which is, essentially, one month). Our results provide convincing evidence that the majority of judges do care. Nearly $43 \%$ of the surveyed population replied "definitely yes", 24\%-“yes", 14\%—“it is important to me", and a similar proportion that "I try to take this into consideration". The following answers: "not at all", "hardly", and "slightly (to some extent)" received the support of no more than 1-2\% of the surveyed group of judges (per answer). To give these findings more substance, we may summarize that more than $80 \%$ of judges do care about the number of resolved cases (as revealed by the answers

\footnotetext{
${ }^{20}$ The percentage values that we present in the description of the data obtained from the survey relate to those respondents that provided their answers to the given question(s). With regard to many questions, missing data was not a significant problem (e.g. in the case of "gender" six respondents submitted blank answers), but in cases when it was more severe, we mention this deliberately in the text.
} 
"definitely yes", "yes", and "it is important to me"), signifying an overwhelming majority. This is important information about their productivity, which we strive to explain with the use of data collected based on other questions included in the survey. On the one hand, care for the number of resolved cases signifies that judges are motivated to be productive. On the other hand, whether such care means that judges maximize their utility by striving to solve more cases, thereby imposing their preferences on society, as proposed by Posner (1973), remains an open question. ${ }^{21}$ For example, a judge may strive to adjust the number of rulings they make so as not to deviate from the average for their department, boosting their productivity whenever a lag is observed. Such care may also stem from the competition among judges to resolve a greater number of cases. This is particularly likely to occur when a judge is applying for vertical promotion, where comparison of statistical output is one of the evaluation criteria. All in all, these actions can be considered as examples of how judges rationalize their behavior.

Nearly $84 \%$ of females and nearly $75 \%$ of males in our sample care for the number of cases resolved. Whether the respondent has children does not seem to affect this figure in a significant way (81\% of judges with children, and $77 \%$ of those without, do care for the number of resolved cases). Very similar levels of care are undertaken by judges both at district and regional courts ( $80 \%$ and $81 \%$ answered "definitely yes", "yes", or "it is important to me", respectively). A slightly more diverse picture is revealed by the data on care among respondents in different work experience duration categories. These data are presented in Fig. 2. Judges with less than five years of work experience demonstrate less care in comparison with the aggregate results for the entire sample (nearly $76 \%$ do care), while judges with more than 20 years of experience care more $(86 \%){ }^{22}$ There seems to be, therefore, a stronger desire to increase productivity among judges with longer work experience than among younger judges. While at first sight counter-intuitive, given that longer work experience will usually result in more expertise, this finding is in line with the conclusions of the literature mentioned earlier (e.g. Christensen and Szmer 2012), albeit with no confirmation of a burnout effect.

The main interest in this paper concerns the factors affecting judges' productivity and their career choices. With regard to the first aspect, respondents were asked about the role of the following aspects suggested by the literature surveyed earlier: their remuneration, the possibility of promotion to a higher instance court, the threat of revocation of their judgment, and their service/mission. Given the Polish institutional setting within which the judge operates, we also asked the respondents about the following aspects: periodic assessment, the threat of a complaint about protracted proceedings, the threat of disciplinary proceedings, and the threat of destabilization of their employment relationship.

\footnotetext{
${ }^{21}$ Our data reveal that $55 \%$ of judges take the number of cases resolved into account in their adjudicating activity, while $45 \%$ do not; however, only slightly more than $20 \%$ of respondents overall provided an answer to this question, therefore we treat this result with caution.

${ }^{22}$ For the remaining groups, the results follow the aggregate pattern, i.e. with the share of answers "definitely yes", "yes", and "it is important to me" oscillating around $80 \%$.
} 
The results of the survey concerning factors affecting judges' productivity are presented in Fig. 3. In the case of these questions, 30-60\% of respondents preferred not to answer, submitting blank responses. Taking into account only those that participated, for the majority of judges, the service/mission $(91 \%),{ }^{23}$ the threat of a complaint about protracted proceedings $(69 \%)$, the threat of disciplinary proceedings $(56 \%)$, and the threat of revocation of their judgement $(50 \%)$ were reported as significant factors affecting productivity. Slightly less than half of the respondents consider that the possibility of promotion to a higher court may affect the number of cases which they resolve (43\%). Aspects such as the threat of destabilization of the employment relationship (30\%), periodic assessment (10\%), and, in particular, remuneration $(8 \%)^{24}$ are revealed to be least relevant for the judges in this respect. In addition to these factors, respondents also pointed to other aspects in their replies to the open-ended question. Some of them related to their personal motivationcall of duty or feeling of responsibility (mentioned by 17 out of 43 respondents that answered this question - a factor certainly related to service/mission), time constraints and the number of incoming cases (10 replies), as well as administrative support (6).

As declared earlier, we have supplemented our analysis with the presentation of a description of results concerning judges' career choice motives. Here the questions in the survey concerned whether the following aspects encourage the respondent to pursue their career as a judge: relatively high remuneration, stabilization of the employment relationship, power/authority, status/prestige, social recognition, and leisure. The results of this part of the study are presented in Fig. 4. A sizeable number of respondents refused to submit their answers in this case too (11-55\% depending on the question), so we discuss the findings based on data obtained from those who decided to participate. In the case of career choices, remuneration, as a crucial economic motive, proved to be relatively important, as indicated by $57 \%$ of judges. Two other aspects were, however, significantly more popular among judges - namely stabilization of the employment relationship (94\%) and status/prestige $(78 \%)$. For almost half of the judges, social recognition (43\%) was an important career choice motive. Leisure (23\%) and power/authority (5\%) gained least support among the respondents. From the open-ended question we can infer that the sense of common good is an important career choice driver for judges (24 out of 61 respondents that answered this question provided a common-good or commonjustice related answer). Other factors concerned the fact that judges simply like their work (15 replies), are interested in their work (8) and value their independence (7).

Finally, we supplement the analysis with a focus on the supervision of judges. As explained in Sect. 1, Beenstock and Haitovsky (2004) argued, based on an analysis of Israeli courts, that judges under pressure-for example exerted by members of

\footnotetext{
23 We also asked whether quality was taken into account by the judges in resolving cases, and this was confirmed by $95 \%$ of them (however only slightly more than one-third of respondents overall provided an answer to this question, therefore we treat this result with caution).

24 We are aware that this number may be underestimated given judges' possible reluctance to reveal that they are driven by material incentives. Nevertheless, in comparison with the remaining factors, the role of remuneration seems very weak at best.
} 


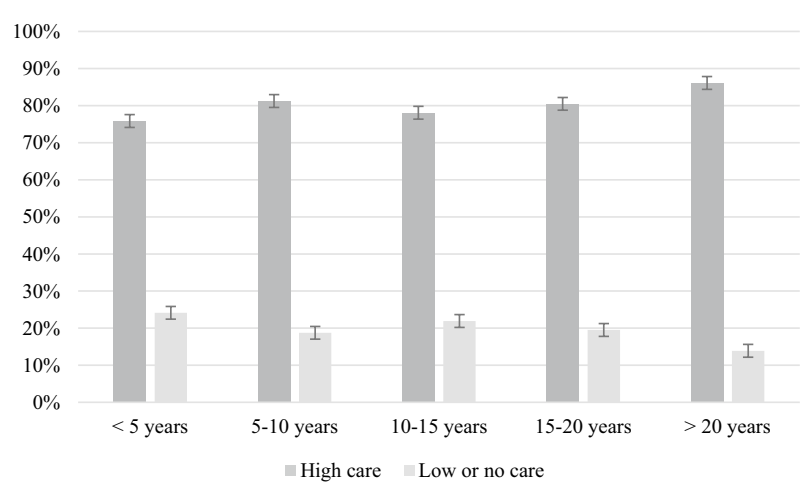

Fig. 2 Duration of judges' work experience and care for the number of resolved cases. Note: Survey question: "Do you care about the number of cases that you resolve per month?" "High care" encompasses answers "yes", "definitely yes", and "it is important to me" (4-6), while "low or no care"- the remaining answers (0-3) Source: Authors' survey

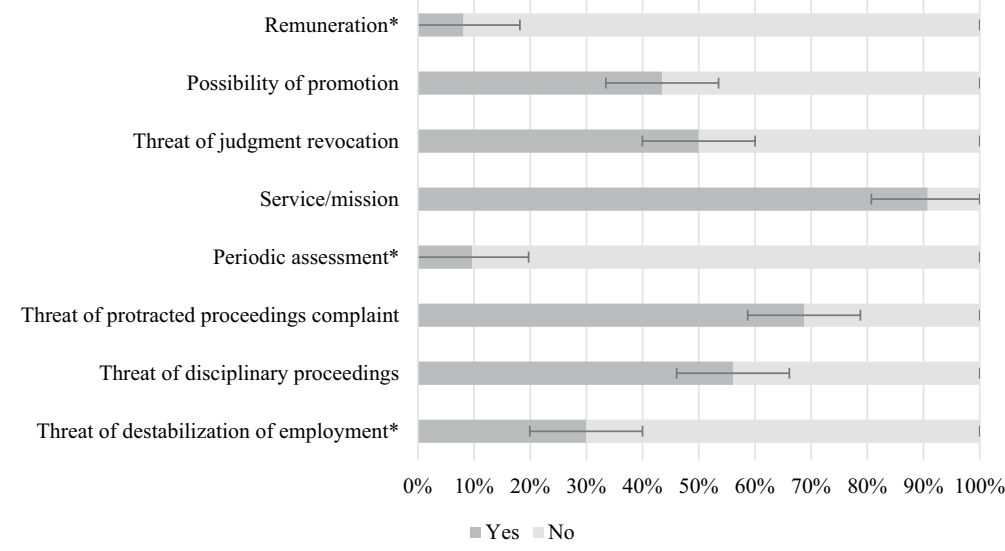

Fig. 3 Factors reported as affecting judges' productivity. Note: *Signifies questions with answers on a 0-6 scale (the remaining ones are yes/no questions). In these cases, "yes" encompasses answers "yes", "definitely yes", and "it is important to me" (4-6), while "no"- the remaining answers (0-3). Source: Authors' survey

a supervisory body (the president or the chairman of the department)-are more productive. We asked our respondents a related question and found that only $18 \%$ of them admit that such supervision by the court president or the chairman of the department affects their productivity in terms of the number of cases resolved. ${ }^{25}$ At the same time, an overwhelming majority of the respondents revealed that they monitor the number of cases that they resolve themselves (81\%). Such self-monitoring is

\footnotetext{
${ }^{25}$ This was one of the questions requiring answers on a 0-6 scale, so the reported proportion reflects the following answers: "definitely yes", "yes" and "it is important to me".
} 


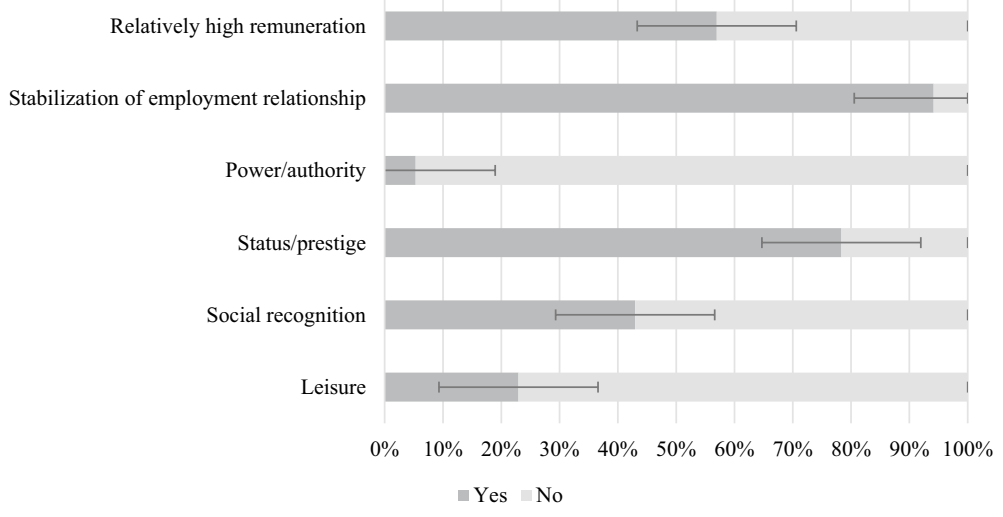

Fig. 4 Judges' career choice motives. Source: Authors' survey

certainly connected with the judges' care for the number of resolved cases that was discussed earlier and their productivity.

\subsection{Statistical analysis}

Due to the limited sample, as well as abundant missing values and other problems, the data obtained from the survey do not allow for a full-fledged, sophisticated statistical or econometric analysis. Nevertheless, in this subsection, we present several basic statistical tests, which to some extent both confirm and refute the findings reported in the descriptive analysis in the previous subsection.

Table 1 presents the descriptive statistics of the data obtained from the survey. In case of a lack of observations, as discussed earlier, the multiple imputation technique was applied (so the number of observations is 252 in all cases). In the course of the imputation, it was necessary to recode the answers provided on a $0-6$ scale to a $0-1$ (yes/no) classification. ${ }^{26}$ This, however, did not concern data on care for the number of cases resolved and self-monitoring of judges, since these series of data were generally free from the problem of missing values.

Table 1 indicates that the distribution of different factors, which affect judges' productivity and career choice motives, is not symmetrical. The size of the skewness coefficient warrants concerns about the normality of the data. ${ }^{27}$ Therefore, with the aim to obtain a "statistically sound" view of the link between various factors reported by the judges as affecting their productivity, as well as their career choice motives, and judges' care for the number of resolved cases, we provide Spearman's

\footnotetext{
${ }^{26}$ Answers 4-6 (i.e. "definitely yes", "yes", and "it is important to me") were coded as positive (value 1 ), while the remaining ones were coded as negative (value 0). This corresponds to the interpretation of respondents' replies to such questions within the discussion of the results that we provided in the previous subsection.

27 The Kolmogorov-Smirnov and Shapiro-Wilk tests, which were also conducted to verify this conjecture, lead to the rejection of the assumption of a normal distribution of our data.
} 
Table 1 Descriptive statistics. Source: Authors' calculations

\begin{tabular}{|c|c|c|c|c|c|c|}
\hline & Minimum & Maximum & Mean & SD & Skewness & Kurtosis \\
\hline \multicolumn{7}{|l|}{ Judges' characteristics } \\
\hline Gender & 1.00 & 2.00 & 1.29 & 0.45 & 0.93 & -1.14 \\
\hline Duration of work experience & 1.00 & 5.00 & 3.38 & 1.33 & -0.29 & -1.01 \\
\hline Having children & 1.00 & 2.00 & 1.17 & 0.38 & 1.73 & 0.98 \\
\hline Type of court & 1.00 & 2.00 & 1.31 & 0.46 & 0.81 & -1.38 \\
\hline \multicolumn{7}{|l|}{ Judges' productivity and its factors } \\
\hline Care for the number of resolved cases & 0.00 & 6.00 & 4.80 & 1.39 & -1.17 & 0.96 \\
\hline Remuneration & 0.00 & 1.00 & 0.01 & 0.09 & 11.16 & 123.47 \\
\hline Possibility of promotion & 0.00 & 1.00 & 0.47 & 0.50 & 0.11 & -2.00 \\
\hline Threat of judgment revocation & 0.00 & 1.00 & 0.49 & 0.50 & 0.03 & -2.02 \\
\hline Service/mission & 0.00 & 1.00 & 0.90 & 0.31 & -2.35 & 5.29 \\
\hline Periodic assessment & 0.00 & 1.00 & 0.09 & 0.29 & 2.86 & 6.20 \\
\hline Threat of protracted proceedings complaint & 0.00 & 1.00 & 0.68 & 0.47 & -0.79 & -1.39 \\
\hline Threat of disciplinary proceedings & 0.00 & 1.00 & 0.53 & 0.50 & -0.13 & -2.00 \\
\hline $\begin{array}{l}\text { Threat of destabilisation of the employ- } \\
\text { ment relationship }\end{array}$ & 0.00 & 1.00 & 0.26 & 0.44 & 1.11 & -0.77 \\
\hline \multicolumn{7}{|l|}{ Judges' career choice motives } \\
\hline Relatively high remuneration & 0.00 & 1.00 & 0.56 & 0.50 & -0.23 & -1.97 \\
\hline Stabilisation of employment relationship & 0.00 & 1.00 & 0.94 & 0.24 & -3.75 & 12.13 \\
\hline Power/authority & 0.00 & 1.00 & 0.02 & 0.15 & 6.28 & 37.79 \\
\hline Status/prestige & 0.00 & 1.00 & 0.79 & 0.41 & -1.46 & 0.13 \\
\hline Social recognition & 0.00 & 1.00 & 0.46 & 0.50 & 0.16 & -1.99 \\
\hline Leisure & 0.00 & 1.00 & 0.23 & 0.42 & 1.29 & -0.34 \\
\hline \multicolumn{7}{|l|}{ Supervision and self-monitoring } \\
\hline Supervision & 0.00 & 1.00 & 0.18 & 0.39 & 1.65 & 0.74 \\
\hline Self- monitoring & 0.00 & 6.00 & 4.91 & 1.43 & -1.37 & 1.35 \\
\hline
\end{tabular}

correlation analysis. Table 2 presents the obtained coefficients and $p$ values. Only for the threat of revocation and self-monitoring does this analysis confirm statistically significant correlation with care for the number of cases resolved. The relevance of no other factors discussed earlier, not even service/mission, nor any of the career choice motives, can be upheld in this respect.

In the next step, we employ the Kruskal-Wallis non-parametric test for $k>2$ populations to verify the equality of distribution functions in the compared populations of judges, who care for the number of resolved cases and those who do not. Specifically, this significance of differences test allows to verify the following null hypothesis $\mathrm{H}_{0}$ : $\mathrm{JUDGE}_{\mathrm{A}}=\mathrm{JUDGE}_{\mathrm{B}}$ (i.e. there is equality of distribution functions of factors reported as affecting judges' productivity and equality of distribution functions of judges' career choice motives in the compared populations of judges who care for the number of resolved cases and those who do not), against the alternative hypothesis $\mathrm{H}_{1}: \mathrm{JUDGE}_{\mathrm{A}} \neq \mathrm{JUDGE}_{\mathrm{B}}$ (i.e. there is no such equality of distribution functions). 
Table 2 Spearman correlations between factors/motives and judges' care for the number of cases resolved. Source: Authors' calculations

\begin{tabular}{|c|c|c|}
\hline & Correlation coefficient & $p$ value \\
\hline \multicolumn{3}{|l|}{ Judges' characteristics } \\
\hline Gender & -0.08 & 0.23 \\
\hline Duration of work experience & 0.10 & 0.11 \\
\hline Having children & -0.02 & 0.76 \\
\hline Type of court & $-1 \times 10^{-3}$ & 0.98 \\
\hline \multicolumn{3}{|l|}{ Factors affecting judges' productivity } \\
\hline Remuneration & 0.04 & 0.54 \\
\hline Possibility of promotion & -0.01 & 0.92 \\
\hline Threat of judgment revocation & $0.17^{*}$ & 0.01 \\
\hline Service/mission & 0.05 & 0.39 \\
\hline Periodic assessment & 0.07 & 0.25 \\
\hline Threat of protracted proceedings complaint & 0.01 & 0.92 \\
\hline Threat of disciplinary proceedings & -0.10 & 0.10 \\
\hline Threat of destabilisation of the employment relationship & 0.09 & 0.15 \\
\hline \multicolumn{3}{|l|}{ Judges' career choice motives } \\
\hline Relatively high remuneration & 0.05 & 0.48 \\
\hline Stabilisation of employment relationship & 0.04 & 0.57 \\
\hline Power/authority & -0.11 & 0.09 \\
\hline Status/prestige & 0.09 & 0.15 \\
\hline Social recognition & -0.01 & 0.92 \\
\hline Leisure & -0.05 & 0.43 \\
\hline \multicolumn{3}{|l|}{ Supervision and self-monitoring } \\
\hline Supervision & 0.11 & 0.09 \\
\hline Self-monitoring & $0.72 *$ & 0.00 \\
\hline
\end{tabular}

*Correlation significant at the $1 \%$ level (two-tailed)

The results are presented in Table 3. Only for self-monitoring can it be concluded that the test results confirm the significance of the differences in the relation of various levels of this variable to the controlled factor (i.e. judges' care for the number of resolved cases) for the two compared populations of judges. Statistically speaking, therefore, only this aspect demonstrates its significant relationship with judges' reported productivity.

The simple statistical tests presented in this subsection do not allow to assess causality, nor the direction of the studied relationship. In fact, we conjecture that the link between self-monitoring and the care for the number of cases that judges resolve might as well take the inverse direction, i.e. judges who care about the number of cases resolved tend to also monitor their activity in this respect, so as to be, ultimately, more productive. What we can conclude, is that a statistically significant relationship between these two aspects of judges' productivity exists. 
Table 3 Kruskal-Wallis test statistics (grouping variable: care for the number of cases heard). Source: Authors' calculations

Kruskal-Wallis H Degrees of $\quad p$ value freedom

\begin{tabular}{lrrl}
\hline Judges' characteristics & & & \\
Gender & 5.55 & 6 & 0.48 \\
Duration of work experience & 3.34 & 6 & 0.77 \\
Having children & 7.29 & 6 & 0.30 \\
Type of court & 0.32 & 6 & 0.99 \\
Factors affecting judges' productivity & & & \\
Remuneration & 1.27 & 6 & 0.97 \\
Possibility of promotion & 6.30 & 6 & 0.39 \\
Threat of judgment revocation & 10.16 & 6 & 0.12 \\
Service/mission & 5.50 & 6 & 0.48 \\
Periodic assessment & 6.70 & 6 & 0.35 \\
Threat of protracted proceedings complaint & 5.86 & 6 & 0.44 \\
Threat of disciplinary proceedings & 4.62 & 6 & 0.59 \\
Threat of destabilisation of the employment relationship & 5.10 & 6 & 0.53 \\
Judges' career choice motives & & & \\
Relatively high remuneration & 5.00 & 6 & 0.54 \\
Stabilisation of employment relationship & 2.13 & 6 & 0.91 \\
Power/authority & 7.23 & 6 & 0.30 \\
Status/prestige & 8.61 & 6 & 0.20 \\
Leisure & 2.44 & 6 & 0.88 \\
Social recognition & 7.76 & 6 & 0.26 \\
Supervision and self-monitoring & & & \\
Supervision & 6.05 & 6 & 0.42 \\
Self-monitoring* & 134.73 & 6 & 0.00 \\
\hline & & &
\end{tabular}

*Significance at the $1 \%$ level

\section{Conclusions}

In discussing the necessary directions of changes within the Polish judiciary, judges are often accused of sluggishness in hearing cases, avoiding decision making, issuing judgments without sufficient evidence, or lack of social sensitivity. In this paper, concentrating on judges' productivity, we related to the first element on this list. Our study focused on the stimulating factors affecting judges' career choices and productivity (measured by the number of cases resolved). The data collected from surveys and interviews conducted in three of Poland's largest regional courts and subordinate district courts, revealed that an overwhelming majority of judges do care for the number of cases that they resolve, i.e. their productivity. Most of them also monitor this quantitative output and this self-monitoring activity (contrary to supervision) is significantly correlated with productivity. In choosing to pursue such a career, Polish judges are guided mainly by prospects of employment stability and status/prestige 
of this profession. Remuneration is also a significant factor in this respect, while the choice of court is irrelevant. Given the uniform regulations in the Polish legal system, the choice of the place of adjudication is not related to the judge's salary, which depends solely on the transition to higher promotion rates (based on duration of work experience and shifting to higher courts). A typical judge in Poland starts their career at a district court. Currently, a clear trend can be observed of applying for judicial vacancies from various places of residence, which is fully in line with the conclusions of our study.

In their care for the number of cases resolved, judges' remuneration is, however, no longer a significant factor, putting in question the conclusions indicating typically financial motivation of judges proposed in some of the economic literature. Non-monetary components in the utility function of judges, hinted by the literature surveyed in Sect. 1, including possibilities of promotion or threat of judgment revocation, also do not seem to play a predominant role. Some aspects of the institutional setting within which Polish judges operate, e.g. the threat of a complaint about protracted proceedings, as well as the threat of disciplinary proceedings, seem to matter to some extent but our limited statistical tests fail to confirm these findings.

We also cannot provide a strong confirmation that, by passing judgments, judges strive to impose their own system of preferences and values on society, deriving utility from it. While judges do care for the number of cases that they resolve and, generally, take this number into account in their adjudicating activity, it is not true that a lower-paid judge aims to settle a greater number of cases so as to boost their utility. More than for the number of cases, Polish judges report to care for their quality. This is connected with the fact that an overwhelming majority of judges revealed their motivation to be providing service to the society, fulfilling a certain mission or duty arising from their profession. This is in line with the approach to judicial behavior combining the time-allocation model proposed by Epstein et al. (2013) with the broad literature on public sector incentives, as well as the expectations expressed in the Polish "Strategy for the Modernization of the System of Justice 2014-2020" (Ministry of Justice 2014), which emphasizes that the justice system exists to provide Polish citizens with the right to justice by performing tasks in an efficient, competent and effective way. It seems that Polish judges are not guided entirely by their own self-interest in adjudicating, being more concerned with values and resembling closer the concept of sociological or institutionally-rooted man than typical homo oeconomicus. To be tested, however, this hypothesis requires a follow-up in-depth study employing behavioral and evolutionary models.

Our results provide insights concerning the validity of the main predictions of the economic approach to explaining judicial behavior for Poland-a post-socialist country striving to increase judicial efficiency, with a relatively large population of judges and for which the number of judges has been confirmed to matter for the overall efficiency of the judicial system. However, the information obtained from judges within our study on the factors shaping their productivity may become a helpful tool in systemizing knowledge concerning the perspectives and directions of changes which are necessary to set up an efficient justice system, not only in Poland but also elsewhere. Specifically, it may contribute to the formulation of postulates about the need to carry out legislative changes aimed at the simplification of 
procedures, which are currently delaying court proceedings in many post-socialist countries. It may also aid in promoting the proper attitude and behavior of judges in terms of meeting social expectations related to the recognition of cases within a reasonable timeframe. This, in turn, may facilitate successful functioning of the market economy, as well as contribute to increased levels of citizens' trust in the legal system-an outstanding challenge for many post-socialist countries.

\section{Appendix 1: Basic information about the Polish judicial system and judges}

Pursuant to Article 175(1) of the Constitution of the Republic of Poland of 2 April $1997,{ }^{28}$ the justice system in Poland is governed by the Supreme Court, common courts, administrative courts and military courts. In Poland there are 374 common courts, including 11 courts of appeal, 45 regional courts and 318 district courts. Figure 5 shows the territorial division between courts of appeals, and within it the number of regional courts, in graphical form.

Article 1(2) of the Act of 27 July 2001-Law on the system of common courts ${ }^{29}$ confirms the presumption of jurisdiction of common courts provided for in Article 177 of the Constitution of the Republic of Poland, which is intended to avoid competence disputes between them and other courts, i.e. administrative and military courts, which from this point of view are a type of special court (Górski 2013). Pursuant to Article 1(1) of the Act of 8 December 2017 on the Supreme Court, ${ }^{30}$ this court is a judicial authority established to exercise justice by:

(1) Supervision over the legality and uniformity of the jurisprudence of common and military courts;

(2) Passing legal resolutions resolving legal issues;

(3) Resolving other matters specified in the Acts.

The essence of judicial supervision lies primarily in the control of the correctness of lower-instance court decisions by the appellate court, by examining appeals lodged against such decisions by entitled entities. Thus, the regional court supervises the jurisprudence of the district courts in its district and the court of appeal supervises the jurisprudence of the regional courts. This is the so-called instance supervision. A similar function in relation to courts of appeal throughout the country is performed by the Supreme Court, which examines cassation complaints, complaints about the non-compliance of a final decision with the law, complaints andin criminal cases-motions to declare the decision invalid (Górski 2013).

\footnotetext{
28 Journal of Laws No. 78, item 483, with amendments.

29 Journal of Laws of 2020, item 365, with amendments.

30 Journal of Laws of 2019, item 825, with amendments.
} 
A district court shall be established for one or more municipalities (in justified cases, more than one district court within the same municipality may be established) with a population of at least 50,000 if the total number of civil, criminal, family and juvenile cases entering an existing district court from the territory of that municipality or several municipalities is at least 5000 per calendar year. A regional court is established for the area of jurisdiction of at least two district courts, and a court of appeal for the area of jurisdiction of at least two court districts.

The courts are divided into departments. In district courts the following departments can be created: civil, criminal, family and juvenile, work, social security or work and social insurance, business, land and mortgage registers and enforcement. The following departments can be created in regional courts: civil, penal, labor, social security or labor and social insurance and economic control of telecommunications, postal and Internet data. Courts of appeal are divided into civil, criminal and labor and social security departments.

The organs of the courts are: in district courts, the Court President and in principle the Court Director (in a district court where no Court Director is appointed, the tasks of the Court Director are performed by the superior court's Director, who also takes over the financial management of that court); in regional courtsthe Court President, Court College and Court Director; and in courts of appealthe Court President, Court College and Court Director.

Among the most important competences of the Court President, the following should be indicated:

1) directing and representing the court outside (except in cases falling within the competence of the Court Director), and in particular:

(a) managing the administrative activities of the court, in particular ensuring the proper conduct of the internal administration of the court, directly related to the performance of the court's tasks;

(b) professional authority over judges, judicial assessors, court registrars, judicial assistant judges of the court concerned and the managers and experts of the court's expert advisory panel;

(c) entrusting and dismissing judges, assessors and legal secretaries of the court;

(d) analyzing the case law in the managed court in terms of the level of its uniformity and informing judges and court assessors of the results of this analysis and, if significant discrepancies in case law are found, informing the First President of the Supreme Court about them.

As far as managing the administrative activities of the court is concerned, the Court President reports to the superior court's President and to the Minister of Justice.

The most important competences of the Court Director are: 


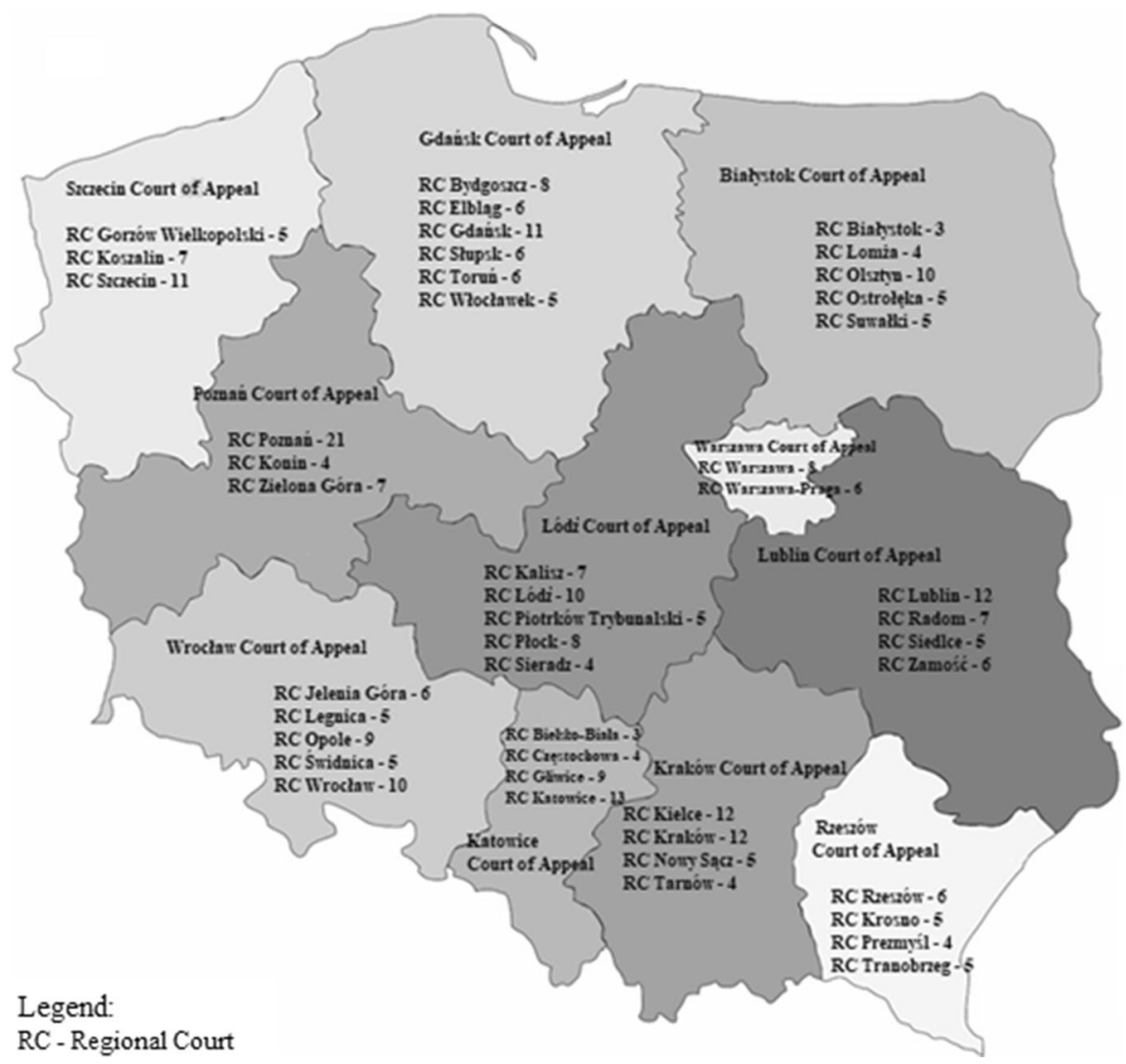

Fig. 5 Number of regional courts in particular appeal districts in Poland. Source: Authors' graph

(1) Managing the administrative activity of the court, which consists of ensuring the appropriate technical and organizational conditions for the functioning of the court and the performance of tasks by the court;

(2) The performance of financial, economic and financial control tasks;

(3) Being the official superior of the court and performing activities in the field of labor law, as well as representing the court in this respect towards the court's employees, with the exception of judges, court assessors, court registrars, court superintendents, court assistant judges and managers, as well as opinion-forming specialists of court specialist teams;

(4) Determining, in agreement with the president of the court, the distribution and number of individual positions in the departments of the court where court employees are employed, with the exception of judges, court assessors, court registrars, professional curators and judges' assistants.

The judgment of the court of first instance may be appealed to the court of second instance. In case: 
(1) the appeal is upheld, the court of second instance shall change the appealed judgment and rule on the merits;

(2) the court of second instance annuls the judgment under appeal, it discontinues the proceedings to the extent that they are null and void and refers the case back to the court of first instance;

(3) if the claim is rejected or there are grounds to discontinue the proceedings- the court of second instance shall set aside the judgment and reject the claim or discontinue the proceedings;

(4) if the court of first instance fails to consider the merits of the case or if the delivery of the judgment requires that evidence be taken in full-the court of second instance may revoke the appealed judgment and refer the case back to the court of first instance.

On the other hand, a party, the General Prosecutor, the Ombudsman or the Children's Rights Ombudsman may file a cassation appeal with the Supreme Court against a final judgment or order of the court of second instance to reject a statement of claim or discontinue proceedings ending the case.

The judge's remuneration depends on duration in work experience and the associated promotion rate. A judge's monthly salary is calculated as the product of the promotion rate and the average salary determined in Poland for each year. Assuming that in 2019 the average salary in Poland was PLN 4839.24, the judge's salary depending on the promotion rate was respectively:

(1) at a district court:

(a) first rate: $2.05-P L N 9920$ (gross);

(b) second rate: $2.17-\mathrm{PLN} 10,501$ (gross);

(c) third rate: 2.28-PLN 11,033 (gross);

(d) fourth rate: 2.36 -PLN 11,420 (gross);

(e) fifth rate: $2.50-$ PLN 12,098 (gross);

(2) at a regional court:

(a) fourth and fifth rates (as at the district court, i.e. 2.36 and 2.50);

(b) sixth rate: 2.65 (PLN 12,823 gross);

(c) seventh rate: 2.75 PLN 13,307 (gross);

(d) eighth rate: $2.92-\mathrm{PLN} 14,130$ (gross);

(3) at a court of appeal:

(a) seventh and eighth rates (as at the regional court, i.e. 2.75 and 2.92);

(b) ninth rate: 3.12 (PLN 15,098 gross);

(c) tenth rate: 3.23 (PLN 15,630 gross). ${ }^{31}$

31 Art. 91 and 91a of the Act on the System of Common Courts, Journal of Laws 2016, item 483, with amendments. 
Open Access This article is licensed under a Creative Commons Attribution 4.0 International License, which permits use, sharing, adaptation, distribution and reproduction in any medium or format, as long as you give appropriate credit to the original author(s) and the source, provide a link to the Creative Commons licence, and indicate if changes were made. The images or other third party material in this article are included in the article's Creative Commons licence, unless indicated otherwise in a credit line to the material. If material is not included in the article's Creative Commons licence and your intended use is not permitted by statutory regulation or exceeds the permitted use, you will need to obtain permission directly from the copyright holder. To view a copy of this licence, visit http://creativecommons.org/licen ses/by/4.0/.

\section{References}

Ash, E., \& McLeod, W. B. (2015). Intrinsic motivation in public service: Theory and evidence from state Supreme Courts. The Journal of Law and Economics, 58(4), 863-913.

Baum, L. (1997). The puzzle of judicial behavior. Ann Arbor: University of Michigan Press.

Baum, L. (2006). Judges and their audiences: A perspective on judicial behavior. Princeton, NJ: Princeton University Press.

Baum, L. (2010). Motivation and judicial behavior: Expanding the scope of inquiry. In D. E. Klein \& G. Mitchell (Eds.), The Psychology of Judicial Decision Making (pp. 3-26). Oxford: Oxford University Press.

Beenstock, M., \& Haitovsky, Y. (2004). Does the appointment of judges increase the output of the judiciary? International Review of Law and Economics, 24, 351-369.

Bełdowski, J., Dąbroś, L., \& Wojciechowski, W. (2020). Judges and court performance: A case study of district commercial courts in Poland. European Journal of Law and Economics. https://doi. org/10.1007/s10657-020-09656-4.

CEPEJ-European Commission for the Efficiency of Justice. (2018). European judicial systems. Efficiency and quality of justice. CEPEJ Studies. Strasbourg: Council of Europe Publishing.

Choi, S., Gulati, M., \& Posner, E. A. (2009). Are judges overpaid? Journal of Legal Analysis, 1(1), 47-117.

Choi, S., Gulati, M., \& Posner, E. A. (2012). What do federal district judges want? An analysis of publications, citations, and reversals. The Journal of Law, Economics, and Organization, 28(3), 518-549.

Christensen, R., \& Szmer, J. (2012). Examining the efficiency of the U.S. courts of appeals: Pathologies and prescriptions. International Review of Law and Economics, 32, 30-37.

Citko, A. (2015). Nie takie niskie zarobki sędziow w Polsce (Salaries of judges in Poland not so low). Prawo Europejskie w praktyce, 1(127), 11-17.

Cohen, M. A. (1991). Explaining judicial behavior or What's 'unconstitutional' about the sentencing commission? Journal of Law Economics and Organization, 7, 183-199.

Cohen, M. A. (1992). The motives of judges: Empirical evidence from antitrust sentencing. International Review of Law and Economics, 12, 13-30.

Cooter, R. (1983). The objectives of private and public judges. Public Choice, 41, 107-132.

Di Vita, G. (2010). Production of laws and delays in court decisions. International Review of Law and Economics, 30(3), 276-281.

Dimitrova-Grajzl, V., Grajzl, P., Slavov, A., \& Zajc, K. (2015). Courts in a transition economy: Case disposition and the quantity-quality tradeoff in Bulgaria. Economic Systems, 40(1), 18-38.

Dimitrova-Grajzl, V., Grajzl, P., Sustersic, J., \& Zajc, K. (2012a). Court output, judicial staffing, and the demand for court services: Evidence from Slovenian Courts of First Instance. International Review of Law and Economics, 32, 19-29.

Dimitrova-Grajzl, V., Grajzl, P., \& Zajc, K. (2014). Understanding modes of civil case disposition: Evidence from Slovenian courts. Journal of Comparative Economics, 4, 924-939. 
Dimitrova-Grajzl, V., Grajzl, P., Zajc, K., \& Sustersic, J. (2012b). Judicial incentives and performance at lower courts: Evidence from Slovenian judge-level data. Review of Law and Economics, 8(1), 215-252.

Djankov, S., La Porta, R., Lopez-de Silanes, F., \& Shleifer, A. (2003). Courts. The Quarterly Journal of Economics, 118(2), 453-517.

Dobbin, S. A., Gatowski, S. I., Ginsburg, G. P., Merlino, M. L., Dahir, V., \& Richardson, J. T. (2001). Surveying difficult populations: lessons learned from a national survey of State Trial Court Judges. The Justice System Journal, 22(3), 287-314.

Eisenberg, T., \& Huang, K-Ch. (2012). The effect of rules shifting supreme court jurisdiction from mandatory to discretionary-An empirical lesson from Taiwan. International Review of Law and Economics, 32, 3-18.

Epstein, L., \& Knight, J. (2013). Reconsidering judicial preferences. The Annual Review of Political Science, 16, 11-31.

Epstein, L., Landes, W. M., \& Posner, R. A. (2013). The behavior of federal judges. Cambridge, MA: Harvard University Press.

European Commission. (2018). The 2018 EU Justice Scoreboard. Brussels. https://doi.org/10.2838/72153 . Retrieved form 20 July 2020

Foxall, G. R. (2004). What judges maximize: Toward an economic psychology of the judicial utility function. Liverpool Law Review, 25, 177-194.

Gomes, A. O., Guimaraes, T. A., \& De Souza, E. C. L. (2016). Judicial work and judges' motivation: The perceptions of Brazilian State Judges. Law and Policy, 38(2), 162-176.

Górski, A. (ed.) (2013). Prawo o ustroju sqdow powszechnych. Komentarz (Law on the system of common courts. A commentary). OpenLEX System, https://sip.lex.pl/komentarze-i-publikacje/komen tarze/prawo-o-ustroju-sadow-powszechnych-komentarz-587355082. Retrieved from 24 July 2020.

Guerra, A., \& Tagliapietra, C. (2017). Does judge turnover affect judicial performance? Evidence from Italian Court records. Justice System Journal, 38(1), 52-77.

Hansford, T. G., Savchak, E. C., \& Songer, D. R. (2010). Politics, careerism, and the voluntary departures of US District Court Judges. American Politics Research, 38(6), 986-1014.

Higgins, R. S., \& Rubin, P. H. (1980). Judicial discretion. The Journal of Legal Studies, 9(1), 129-138.

Kimenyi, S. M., Shughart, II, W. F. \& Tollison, R. D. (1985). What do judges maximize. Journal of Public Finance and Public Choice, 3, 181-188.

Kornhauser, L. A. (2000). Judicial organization and administration. In B. Bouckaert \& D. De Geest (Eds.), Encyclopedia of Law \& Economics (Procedural Law and Economics). Cheltenham: Edward Elgar.

Landes, W. M., Lessig, L., \& Solimine, M. E. (1998). Judicial influence: A citation analysis of federal courts of appeals judges. Journal of Legal Studies, 27, 271-332.

Landes, W. M., \& Posner, R. A. (1980). Legal change, judicial behavior and the diversity jurisdiction. Journal of Legal Studies, 9, 367-386.

Łukaszewicz, A. (2019). Liczba wakatów w sqdach-Ministerstwo Sprawiedliwości podało dane (Number of vacancies at the courts-the Ministry of Justice provided the data). Rzeczpospolita, 10(01), 2019.

Macey, J. R. (1994). Judicial preferences, public choice, and the rules of procedure. Journal of Legal Studies, 23, 627-646.

Magalhães, P. C., \& Garoupa, N. (2020). Judicial performance and trust in legal systems: Findings from a decade of surveys in over 20 European Countries. Social Science Quarterly, 101(5), 1743-1760.

Marciano, A., \& Khalil, E. L. (2012). Optimization, path dependence and the law: Can judges promote efficiency? International Review of Law and Economics, 32, 72-82.

Melcarne, A., \& Ramello, G. (2015). Judicial independence. Judges' Incentives and Efficiency, Review of Law and Economics, 11(2), 149-169.

Miceli, T. J., \& Cosgel, M. M. (1994). Reputation and judicial decision-making. Journal of Law Economics and Organization, 23, 31-51.

Ministry of Justice. (2014). Strategia modernizacji przestrzeni sprawiedliwości na lata 2014-2020 (Strategy for the modernization of the justice space for the years 2014-2020). Warsaw. https://www.gov. pl/attachment/8ebd5d1b-1ea0-48d0-ab08-4fa7119c36a5. Retrieved from 21 July 2020.

Ministry of Justice. (2016a). Struktura sqdow powszechnych (The structure of common courts). https:// dane.gov.pl/dataset/985,lista-sadow-powszechnych/resource/3900/table. Retrieved from 24 July 2020 . 
Ministry of Justice. (2016b). Zatrudnieni w sqdownictwie powszechnym (Paid employees in common courts). https://isws.ms.gov.pl/pl/baza-statystyczna/opracowania-wieloletnie/download,2853,13. html. Retrieved from 25 July 2020.

Ministry of Justice (2018). Ogólna ewidencja spraw $w$ sqdach powszechnych $w$ Polsce (The number of incoming, resolved and pending cases in common courts in Poland). https://isws.ms.gov.pl/pl/bazastatystyczna/opracowania-wieloletnie/download,2853,8.html. Retrieved from 25 July 2020.

National Council of Judiciary. (2012). Wnioski wynikajace z raportu o stanie kadry sędziowskiej (Conclusions from the report on the state of the judicial staff). http://www.inpris.pl/fileadmin/user_upload/ documents/Biblioteka_MWS/39.pdf. Retrieved from 11 July 2020.

OECD. (2013). Judicial performance and its determinants: a cross-country perspective, OECD Economic Policy Paper, No. 05, OECD.

Posner, R. A. (1973). Economic analysis of law. Boston: Little, Brown and Company.

Posner, R. A. (1993). What do judges and justices maximize? (The same thing everybody else does). Supreme Court Economic Review, 3, 1-41.

Posner, R. A. (2008). How judges think. Cambridge, MA: Harvard University Press.

Ramello, G., \& Voigt, S. (2012). Introduction. The economics of efficiency and the judicial system. International Review of Law and Economics, 32, 1-2.

Ramseyer, J. M. (2012). Talent matters: Judicial productivity and speed in Japan. International Review of Law and Economics, 32, 38-48.

Schauer, F. (2000). Incentives, reputation, and the inglorious determinants of judicial behavior. University of Cincinnati Law Review, 68, 615-636.

Shepherd, J. (2011). Measuring maximizing judges: Empirical legal studies, public choice theory, and judicial behavior. University of Illinois Law Review, 2011, 1753-1766.

Siemaszko, A., Gruszczyńska, B., Marczewski, M., Ostaszewski, P., \& Wiecek-Durańska, A. (2016). Sadownictwo. Polska na tle pozostatych krajów Unii Europejskiej (The judiciary. Poland in comparison with other countries of the European Union). Warsaw: Instytut Wymiaru Sprawiedliwości.

Taha, A. (2004). Publish or Paris? Evidence of how judges allocate their time. American Law and Economics Review, 6, 1-27.

Tjoflat, G. B. (1993). More judges, less justice. American Bar Association Journal, 79(7), 70-73.

Voigt, S. (2016). Determinants of judicial efficiency: A survey. European Journal of Law and Economics, 42(2), 183-208.

Voigt, S., \& El-Bialy, N. (2015). Identifying the determinants of aggregate judicial performance: Taxpayers' money well spent? European Journal of Law and Economics, 41(2), 283-319.

Publisher's Note Springer Nature remains neutral with regard to jurisdictional claims in published maps and institutional affiliations.

\section{Authors and Affiliations}

\section{Przemysław Banasik ${ }^{1} \cdot$ Katarzyna Metelska-Szaniawska² . Małgorzata Godlewska ${ }^{3}$. Sylwia Morawska ${ }^{3}$}

Przemysław Banasik

przemyslawbanasik@tlen.pl

Katarzyna Metelska-Szaniawska

kmetelska@wne.uw.edu.pl

Małgorzata Godlewska

mgodlews@sgh.waw.pl

1 Faculty of Management and Economics, Gdańsk University of Technology, ul. G. Narutowicza 11/12, 80-233 Gdańsk, Poland

2 Faculty of Economic Sciences, University of Warsaw, ul. Długa 44/50, 00-241 Warsaw, Poland

3 Collegium of Business Administration, SGH Warsaw School of Economics, Al. Niepodległości 162, 02-554 Warsaw, Poland 